\title{
PENGARUH UKURAN PERUSAHAAN, UMUR PERUSAHAAN, PROFITABILITAS, SOLVABILITAS, UKURAN KAP, DAN OPINI AUDITOR TERHADAP AUDIT DELAY
}

\author{
Fitria Ingga Saemargani \\ Prodi Akuntansi Universitas negeri Yogyakarta \\ fitria.ingga@ymail.com
}

Rr. Indah Mustikawati, M.Si., Ak.

Staf Pengajar Jurusan P. Akuntansi Universitas Negeri Yogyakarta

\begin{abstract}
Abstrak: Pengaruh Ukuran Perusahaan, Umur Perusahaan, Profitabilitas, Solvabilitas, Ukuran Kap, Dan Opini Auditor Terhadap Audit Delay. Penelitian ini bertujuan untuk mengetahui pengaruh Ukuran Perusahaan, Umur Perusahaan, Profitabilitas Perusahaan, Solvabilitas Perusahaan, Ukuran KAP, dan Opini Auditor terhadap Audit Delay baik secara parsial maupun simultan terhadap Audit Delay pada perusahaan LQ 45 tahun 2011-2013. Penelitian ini merupakan penelitian kausal komparatif dengan pendekatan ex post facto. Teknik pengambilan sampel yang digunakan menggunakan teknik purposive sampling. Sampel berjumlah 14 perusahaan dari perusahaan LQ 45 yang terdaftar di Bursa Efek Indonesia tahun 2011-2013, sehingga data penelitian yang dianalisis berjumlah 42. Teknik analisis data yang digunakan adalah statistik deskriptif, uji asumsi klasik, dan analisis regresi linier berganda. Hasil penelitian menunjukkan bahwa Umur Perusahaan dan Profitabilitas Perusahaan berpengaruh signifikan terhadap Audit Delay, sedangkan Ukuran Perusahaan, Solvabilitas Perusahaan, Ukuran KAP, dan Opini Auditor tidak mempunyai pengaruh yang signifikan terhadap Audit Delay. Secara simultan Ukuran Perusahaan, Umur Perusahaan, Profitabilitas Perusahaan, Solvabilitas Perusahaan, Ukuran KAP, dan Opini Auditor berpengaruh signifikan terhadap Audit Delay pada perusahaan LQ 45 yang terdaftar di Bursa Efek Indonesia tahun 2011-2013.
\end{abstract}

Kata Kunci: Ukuran Perusahaan, Umur Perusahaan, Profitabilitas Perusahaan, Solvabilitas Perusahaan, Ukuran KAP, Opini Auditor, Audit Delay.

Abstract: The Influence Of Company Size, The Age Of Company, Profitability, Solvability, Size Of Public Accountant, And Auditor's Opinion Towards The Audit Delay. This research purposed to know the influence of company size, the age of company, profitability, solvability, size of public accountant, and auditor's opinion towards the audit delay in the index LQ 45 company listed on the Indonesia Stock Exchange 2011-2013. This research use secondary data from Indonesia Stock Exchange (IDX) websites. Purposive sampling technique is used in this research and there are 14 samples collected by this technique. Technique of data analysis in this research used multiple linear regression that has previously been fulfilled the classical assumption test. The results showed the age of company and profitability had influence to the audit delay, while the company size, solvability, size of public accountant, and auditor's opinion didn't significant influence to the audit delay. Simultaneous significance test concluded that company size, the age of company, profitability, solvability, size of public accountant, and auditor's opinion influences audit delay. Simultaneously, company size, the age of company, profitability, solvability, size public accountant, and auditor's opinion exhibited significantly effect to the audit delay of LQ 45 company listed on Indonesia Stock Exchange 2011-2013.

Keywords: company size, the age of company, profitability, solvability, size public accountant, auditor's opinion, audit delay. 


\section{JURNAL NOMINAL / VOLUME IV NOMOR 2 / TAHUN 2015}

\section{PENDAHULUAN}

Laporan keuangan merupakan sesuatu yang sangat penting untuk keberlangsungan perusahaan terutama perusahaan yang sudah go public. Menurut Zaki Baridwan (2004: 17), laporan keuangan adalah ringkasan proses pencatatan dari transaksi-transaksi keuangan yang terjadi selama satu tahun buku yang bersangkutan. Salah satu kewajiban perusahaan yang sudah terdaftar di Bursa Efek Indonesia adalah mempublikasikan laporan keuangan yang telah diaudit oleh Akuntan Publik. Pada Sepetember 2003, Bapepam mengeluarkan peraturan terbaru yaitu Peraturan Pasar Modal No. KEP 36/PM/2003 mengenai kewajiban penyampaian laporan keuangan berkala. Keputusan tersebut menyatakan bahwa laporan keuangan tahunan harus disertai dengan laporan audit dengan pendapat yang lazim dan disampaikan selambat-lambatnya pada akhir bulan ke tiga setelah tanggal laporan keuangan tahunan.

Audit Delay adalah lamanya waktu penyelesaian audit yang diukur dari tanggal penutupan tahun buku sampai tanggal diselesaikannya laporan audit independen (Wiwik Utami, 2006). Menurut Subekti dan Widiyanti dalam Esynasali (2014), Audit Delay adalah perbedaan waktu antara tanggal laporan keuangan dengan tanggal opini audit dalam laporan keuangan mengindikasikan tentang lamanya waktu penyelesaian audit yang dilakukan oleh auditor. Beberapa faktor yang kemungkinan menjadi penyebab Audit Delay semakin lama, yaitu: Ukuran Perusahaan, Umur Perusahaan, Profitabilitas Perusahaan, Solvabilitas Perusahaan, Ukuran KAP, dan Opini Auditor.

Ukuran Perusahaan adalah besar kecilnya suatu perusahaan yang dilihat dari besarnya aset yang dimiliki oleh perusahaan tersebut. Dalam penelitian yang dilakukan oleh Novelia Sagita Indra dan Dicky Arisudhana (2012), Ukuran Perusahaan tidak mempunyai pengaruh yang signifikan terhadap Audit Delay. Hasil penelitian tersebut menjelaskan bahwa Ukuran Perusahaan tidak mempengaruhi Audit Delay karena penilaian ukuran perusahaan menggunakan total assets lebih stabil dibandingkan dengan menggunakan market value dan tingkat penjualan, sehingga Ukuran Perusahaan yang dinilai dengan total assets tidak mempengaruhi lamanya Audit Delay. Berbeda dengan hasil penelitian yang dilakukan oleh Ani Yuliyanti (2011) yang menyatakan bahwa Ukuran Perusahaan mempunyai pengaruh yang signifikan terhadap lamanya Audit Delay, karena semakin besar perusahaan maka semakin baik pula pengendalian internal perusahaan tersebut sehingga dapat 


\section{JURNAL NOMINAL / VOLUME IV NOMOR 2 / TAHUN 2015}

mengurangi tingkat kesalahan dalam penyajian laporan keuangan yang akan memudahkan auditor dalam melakukan pengauditan atas laporan keuangan tersebut.

Umur Perusahaan adalah lamanya perusahaan tersebut beroperasi. Hasil penelitian yang dilakukan oleh Novelia Sagita Indra dan Dicky Arisudhana (2012) menyatakan bahwa semakin lama umur perusahaan, maka Audit Delay yang terjadi semakin kecil, karena perusahaan yang memiliki umur lebih tua dinilai lebih mampu dalam mengumpulkan, memproses, dan menghasilkan informasi pada saat diperlukan karena telah memiliki pengalaman yang cukup banyak dalam hal tersebut. Hasil penelitian yang dilakukan oleh Armanto Witjaksono dan Mega Silvia menyebutkan bahwa Umur Perusahaan tidak berpengaruh terhadap Audit Delay. Perusahaan yang telah beroperasi lama tidak menjamin penyelesaian audit akan semakin cepat karena kompeksitas laporan keuangan.

Profitabilitas Perusahaan adalah kemampuan suatu perusahaan untuk memperoleh laba dalam hubungan dengan penjualan, total aktiva, maupun modal sendiri. Hasil penelitian Dewi Lestari (2010) menunjukkan bahwa Profitabilitas Perusahaan berpengaruh signifikan terhadap Audit Delay. Perusahaan yang mempunyai tingkat profitabilitas yang tinggi cenderung ingin segera mempublikasikannya karena akan mempertinggi nilai perusahaan di mata pihak-pihak yang berkepentingan. Sementara perusahaan yang memiliki tingkat profitabilitas yang rendah kecenderungan yang terjadi adalah kemunduran publikasi laporan keuangan. Namun hasil yang berbeda diperoleh dalam penelitian Ani Yuliyanti (2011) yang menyatakan bahwa Profitabilitas Perusahaan tidak mempunyai pengaruh yang signifikan terhadap Audit Delay.

Solvabilitas Perusahaan adalah kemampuan perusahaan untuk memenuhi seluruh kewajiban finansialnya pada saat perusahaan tersebut diikuidasi. Hasil penelitian Dewi Lestari (2010), Solvabilitas Perusahaan mempunyai pengaruh signifikan terhadap audit delay. Rasio solvabilitas yang tinggi mengakibatkan panjangnya waktu yang dibutuhkan dalam penyelesaian audit. Namun pada penelitian yang dilakukan oleh Ani Yuliyanti (2011), Solvabilitas Perusahaan tidak berpengaruh terhadap Audit Delay.

Kantor Akuntan Publik adalah badan usaha yang telah mendapatkan izin dari Menteri Keuangan sebagai wadah bagi para akuntan publik untuk memberikan jasanya. Ukuran Kantor Akuntan Publik (KAP) digolongkan menjadi dua yaitu KAP the big four dan 


\section{JURNAL NOMINAL / VOLUME IV NOMOR 2 / TAHUN 2015}

KAP non the big four. Penelitian yang dilakukan oleh Ani Yuliyanti (2011) menyatakan bahwa ukuran KAP berpengaruh signifikan terhadap Audit Delay. Penelitian tersebut konsisten dengan penelitian yang dilakukan oleh Novelia Sagita Indra dan Dicky Arisudhana yang juga menyatakan bahwa ukuran KAP mempunyai pengaruh yang siginifikan terhadap Audit Delay. Namun berbeda pada penelitian yang dilakukan oleh Esynasali Vioetta Sebayang (2014) yang menyatakan bahwa ukuran KAP tidak berpengaruh terhadap lamanya Audit Delay.

Opini auditor adalah pendapat yang dikeluarkan oleh auditor mengenai kewajaran laporan keuangan auditan, dalam semua hal yang material, yang didasarkan atas kesesuaian penyusunan laporan keuangan tersebut dengan prinsip akuntansi berterima umum (Mulyadi, 2013:19). Hasil dari penelitian Wiwik Utami (2006), opini yang diberikan oeh auditor mempunyai pengaruh yang signifikan terhadap Audit Delay. Namun berbeda pada hasil penelitian yang dilakukan oeh Ani Yuliyanti (2011), opini auditor tidak mempunyai pengaruh yang signifikan terhadap Audit Delay.

\section{METODE PENELITIAN}

Jenis Penelitian

Jenis penelitian ini merupakan penelitian kausal komparatif, yaitu penelitian dengan karakteristik masalah berupa sebab-akibat antara dua variabel atau lebih (Nur Indriantoro dan Bambang Supomo, 2009: 27). Penelitian kausal komparatif merupakan penelitian ex post facto, yaitu meneliti peristiwa yang telah terjadi dengan cara merunut peristiwa tersebut ke belakang untuk mengetahui faktor-faktor yang menyebabkan terjadinya peristiwa tersebut (Sugiyono, 2001: 7). Penelitian ini menggunakan pendekatan kuantitatif, yaitu penelitian yang analisisnya lebih fokus pada data numerik yang diolah menggunakan metode statistika.

\section{Populasi dan Sampel Penelitian}

Populasi penelitian ini adalah perusahaan-perusahaan yang terdaftar dalam indeks LQ 45. Penelitian ini menggunakan data sekunder dalam bentuk laporan keuangan perusahaan. Teknik yang digunakan dalam pengambilan sampel adalah purposive sampling. Purposive samping adalah suatu teknik pengambilan sampel dengan kriteria tertentu dimana sampel sengaja dipilih untuk mewakili populasinya. Kriteria untuk sampel yang yang akan digunakan adalah sebagai berikut: 
1. Perusahaan yang terdaftar dalam indeks LQ 45 selama tiga tahun berturut-turut dari tahun 2011-2013.

2. Perusahaan LQ 45 yang menggunakan mata uang Rupiah dalam laporan keuangannya.

3. Perusahaan LQ 45 tersebut telah menyampaikan laporan keuangan tahunan berturut-turut untuk tahun 2011-2013 dimana di dalamnya terdapat data dan informasi yang dapat digunakan dalam penelitian ini serta laporan keuangan tersebut telah diaudit dan disertai dengan laporan auditor independen.

Berdasarkan kriteria di atas maka perusahaan yang memenuhi syarat dalam penelitian ini sebanyak 14 perusahaan, selama 3 tahun sehingga jumlah observasi sebanyak 42 sampel.

\section{Data, Instrumen, dan Teknik Pengum- pulan}

\section{Data}

Data dalam penelitian ini menggunakan data sekunder yaitu data yang diperoleh secara tidak langsung, berupa laporan keuangan auditan perusahaan yang terdaftar di Bursa Efek Indonesia pada tahun 2011-2013 yang telah di publikasikan. Data dalam penelitian ini diperoleh dari homepage BEI yaitu www.idx.co.id.

Metode pengumpulan data yang digunakan adalah menggunakan metode dokumentasi. Dokumentasi adalah mengumpulkan data sekunder dengan cara meihat atau menyalin catatan kertas kerja yang dianggap berhubungan dengan penelitian (Nur Indriantoro dan Supomo, 2013: 147).

\section{Teknik Analisis Data}

\section{Statistik Deskriptif}

Statistik deskriptif adalah proses transformasi data penelitian dalam bentuk tabulasi sehingga mudah dipahami, tabulasi menyajikan ringkasan, pengaturan, atau penyusunan data dalam bentuk tabel numerik dan grafik (Malinda, 2015). Statistik deskriptif memberikan gambaran atau deskripsi suatu data yang dilihat dari nilai rata-rata, standar deviasi, varian, maksimum, minimun, sum, range, kurtosis dan skewness (Imam Ghozali, 2011: 19).

\section{Uji Asumsi Klasik}
a. Uji Normalitas
b. Uji Autokorelasi
c. Uji Heteroskedastisitas
d. Uji Mutikolonieritas 


\section{JURNAL NOMINAL / VOLUME IV NOMOR 2 / TAHUN 2015}

Uji Hipotesis

\section{Analisis Regresi Linier Berganda}

Regresi linier berganda adalah hubungan secara linier antara dua atau lebih variabel independen dengan variabel dependen. Persamaan regresi linier berganda dapat dirumuskan sebagai berikut :

$Y=a+b_{1} X_{1}+b_{2} X_{2}+b_{3} X_{3}+b_{4} X_{4}+$ $\mathrm{b}_{5} \mathrm{X}_{5}+\mathrm{b}_{6} \mathrm{X}_{6}$

Keterangan :

$\mathrm{Y}=$ Audit Delay

$\mathrm{X}_{1}=$ Ukuran Perusahaan

$\mathrm{X}_{2}=$ Umur Perusahaan

$\mathrm{X}_{3}=$ Profitabilitas Perusahaan

$\mathrm{X}_{4}=$ Solvabilitas Perusahaan

$\mathrm{X}_{5}=$ Opini Auditor

$\mathrm{X}_{6}=$ Ukuran KAP

\section{Uji Regresi Parsial (Uji Statistik t)}

Jika $t_{\text {hitung }}$ lebih besar dibandingkan dengan $t_{\text {tabel }}$ pada taraf signifikansi $5 \%$, maka variabel independen mempunyai pengaruh signifikan. Sebaliknya jika $t_{\text {hitung }}$ lebih kecil dibandingkan $t_{\text {tabel }}$ pada taraf signifikansi 5\%, maka variabel tersebut tidak mempunyai pengaruh yang signifikan.

\section{a. Uji Simultan (Uji F)}

Uji statistik $F$ digunakan untuk menguji pengaruh variabel independen secara bersama-sama terhadap variabel dependen. Kriteria untuk menentukan bahwa hipotesis diterima adalah jika nilai signifikansi $F$ lebih kecil dari taraf signifikansi $5 \%$ dan $\mathrm{F}$ hitung lebih besar daripada F tabel.

b. Koefisien Determinasi

$$
\text { Koefisisen determinasi }
$$

mengukur seberapa jauh kemampuan model dalam menerangkan variasi variabel dependen. Nilai koefisisen determinasi adalah antara nol dan satu. Nilai $\mathrm{R}^{2}$ yang kecil berarti kemampuan variabel-variabel independen dalam menjelaskan variasi variabel dependen sangat terbatas. Nilai yang mendekati satu berarti variabel-variabel independen memberikan hampir semua informasi yang dibutuhkan untuk memprediksi variasi variabel dependen (Imam Ghozali, 2011:97).

HASIL PENELITIAN DAN

\section{PEMBAHASAN}

Uji Asumsi Klasik

\section{Uji Normalitas}

Hasil uji normalitas menunjukkan bahwa nilai Kolmogorov-Smirnov $Z$ sebesar 0,578 dengan signifikansi sebesar 0,892. Hal ini menunjukkan bahwa nilai signifikansi lebih besar dari 0,05 , sehingga dapat diartikan data yang digunakan dalam model regresi berdistribusi normal. 
JURNAL NOMINAL / VOLUME IV NOMOR 2 / TAHUN 2015

\begin{tabular}{llll}
\multicolumn{1}{c}{ Tabel 1. } & \multicolumn{1}{c}{$\begin{array}{l}\text { Rangkuman } \\
\text { Normalitas }\end{array}$} & Hasil & Uji \\
\hline Variabel & $\begin{array}{l}\text { Kolmogorov } \\
\text { Smirnov } Z\end{array}$ & Sig. & Ket \\
\hline $\begin{array}{l}\text { Understanda } \\
\text { rdized } \\
\text { residual }\end{array}$ & 0,578 & 0,892 & Normal \\
\hline \multicolumn{4}{c}{ Sumber: Data diolah, 2011 } \\
\hline
\end{tabular}

\section{Uji Autokorelasi}

Kriteria tidak terjadinya autokorelasi apabila nilai DW terletak antara du dan 4$\mathrm{du}(\mathrm{du}<\mathrm{dw}<4-\mathrm{du})$. Berikut adalah hasil uji autokorelasi:

Tabel 3. Hasil Uji Heteroskedastisitas

\begin{tabular}{lll}
\hline Variabel & Signifikansi & Keterangan \\
$\begin{array}{l}\text { Ukuran } \\
\text { Perusahaan }\end{array}$ & 0,465 & $\begin{array}{l}\text { Tidak terjadi } \\
\text { heteroskedastisi } \\
\text { tas }\end{array}$ \\
\hline $\begin{array}{l}\text { Umur } \\
\text { Perusahaan }\end{array}$ & 0,073 & $\begin{array}{l}\text { Tidak terjadi } \\
\text { heteroskedastisi } \\
\text { tas }\end{array}$ \\
\hline $\begin{array}{l}\text { Profitabilitas } \\
\text { Perusahaan }\end{array}$ & 0,891 & $\begin{array}{l}\text { Tidak terjadi } \\
\text { heteroskedastisi } \\
\text { tas }\end{array}$ \\
\hline $\begin{array}{l}\text { Solvabilitas } \\
\text { Perusahaan }\end{array}$ & 0,089 & $\begin{array}{l}\text { Tidak terjadi } \\
\text { heteroskedastisi } \\
\text { tas }\end{array}$ \\
\hline Ukuran KAP & 0,085 & $\begin{array}{l}\text { Tidak terjadi } \\
\text { heteroskedastisi } \\
\text { tas }\end{array}$ \\
\hline $\begin{array}{l}\text { Opini } \\
\text { Auditor }\end{array}$ & 0,989 & $\begin{array}{l}\text { Tidak terjadi } \\
\text { heteroskedastisi } \\
\text { tas }\end{array}$ \\
\hline
\end{tabular}

Sumber: Data diolah, 2015

\section{Uji Multikolonieritas}

Sumber: Data diolah, 2015

Berdasarkan tabel di atas, diketahui bahwa nilai Durbin-Watson yang diperoleh sebesar 1,987. Nilai ini terletak diantara du $(1,854)$ dan 4-du $(2,146)$ sehingga dapat disimpulkan tidak terjadi autokorelasi.

\section{Uji Heteroskedastisitas}

Berdasarkan tabel di bawah diketahui bahwa nilai signifikansi pada variabel independen lebih besar dari taraf.... signifikansi 0,05. Hal ini berarti bahwa model regresi pada penelitian ini tidak terjadi heteroskedastisitas. 
JURNAL NOMINAL / VOLUME IV NOMOR 2 / TAHUN 2015

Tabel 4. Hasil Uji Multikololinieritas

\begin{tabular}{lccl}
\hline Variabel & $\begin{array}{l}\text { Tolera } \\
\text { nce }\end{array}$ & VIF & Ket \\
\hline $\begin{array}{l}\text { Ukuran } \\
\text { Perusahaan }\end{array}$ & 0,259 & 3,860 & $\begin{array}{l}\text { Non Multi } \\
\text { kololineritas }\end{array}$ \\
\hline $\begin{array}{l}\text { Umur } \\
\text { Perusahaan }\end{array}$ & 0,442 & 2,264 & $\begin{array}{l}\text { Non Multi } \\
\text { kololineritas }\end{array}$ \\
\hline $\begin{array}{l}\text { Profitabilitas } \\
\text { Perusahaan }\end{array}$ & 0,395 & 2,535 & $\begin{array}{l}\text { Non Multi } \\
\text { kololineritas }\end{array}$ \\
\hline $\begin{array}{l}\text { Solvabilitas } \\
\text { Perusahaan }\end{array}$ & 0,359 & 2,782 & $\begin{array}{l}\text { Non Multi } \\
\text { kololineritas }\end{array}$ \\
\hline Ukuran KAP & 0,518 & 1,930 & $\begin{array}{l}\text { Non Multi } \\
\text { kololineritas }\end{array}$ \\
\hline Opini Auditor & 0,864 & 1,158 & $\begin{array}{l}\text { Non Multi } \\
\text { kololineritas }\end{array}$ \\
\hline
\end{tabular}

Sumber: Data diolah, 2015

\section{Uji Hipotesis}

\section{Tabel 5. Hasil Analisis Regresi Linier Berganda}

\begin{tabular}{lrrrl}
\hline Variabel & $\begin{array}{l}\text { Koefisien } \\
\text { Regresi } \\
\text { (B) }\end{array}$ & t-hitung & Sig. & Ket. \\
\hline Konstanta & $-40,311$ & $-0,434$ & 0,667 & \\
\hline $\begin{array}{l}\text { Ukuran } \\
\text { Perusahaan }\end{array}$ & 3,875 & 1,228 & 0,228 & $\begin{array}{l}\mathrm{H}_{1} \\
\text { ditolak }\end{array}$ \\
\hline Umur & $-0,337$ & $-2,156$ & 0,038 & $\begin{array}{l}\mathrm{H}_{2} \\
\text { diterima }\end{array}$ \\
\hline $\begin{array}{l}\text { Profitabilit } \\
\text { as }\end{array}$ & 13,511 & 2,941 & 0,006 & $\begin{array}{l}\mathrm{H}_{3} \\
\text { diterima }\end{array}$ \\
\hline Solvabilitas & $-1,651$ & $-0,100$ & 0,921 & $\begin{array}{l}\mathrm{H}_{4} \\
\text { ditolak }\end{array}$ \\
\hline $\begin{array}{l}\text { Ukuran } \\
\text { KAP }\end{array}$ & $-11,617$ & $-1,188$ & 0,243 & $\begin{array}{l}\mathrm{H}_{5} \\
\text { ditolak }\end{array}$ \\
\hline $\begin{array}{l}\text { Opini } \\
\text { Auditor }\end{array}$ & 8,564 & 1,609 & 0,117 & $\begin{array}{l}\mathrm{H}_{6} \\
\text { ditolak }\end{array}$ \\
\hline Sur: & & & & \\
\hline
\end{tabular}

Sumber: Data diolah, 2015

Pengaruh Ukuran Perusahaan terhadap Audit Delay

Nilai koefisien regresi variabel Ukuran Perusahaan sebesar 3,875 dengan nilai $\mathrm{t}$ hitung sebesar 1,228 lebih kecil dari nilai $\mathrm{t}$ tabel sebesar 2,030 dan nilai signifikansi sebesar 0,228 lebih besar dari 0,05 hal ini berarti bahwa variabel Ukuran Perusahaan tidak mempunyai pengaruh yang signifikan terhadap Audit Delay. Penelitian ini sejalan dengan penelitian yang dilakukan oleh Dewi Lestari (2010) dan Novelia Sagita Indra dan Dicky Arisudhana (2012) yang menyatakan bahwa Ukuran Perusahaan tidak mempunyai pengaruh yang signifikan terhadap Audit Delay. Menurut Dewi Lestari (2010), Ukuran Perusahaan tidak berpengaruh terhadap Audit Delay karena semua perusahaan yang terdaftar di Bursa Efek Indonesia diawasi oleh investor, pengawas permodalan, dan pemerintah. Oleh sebab itu, perusahaan dengan total aset besar maupun kecil mempunyai kemungkinan yang sama dalam menghadapi tekanan atas penyampaian laporan keuangan. Selain itu, auditor juga menganggap bahwa dalam proses pengauditan berapapun jumlah aset yang dimiliki perusahaan akan diperiksa dengan cara yang sama, sesuai dengan prosedur dalam Standar Profesional Akuntan Publik (SPAP).

\section{Pengaruh Umur Perusahaan terhadap Audit Delay}

Nilai koefisien regresi variabel Umur Perusahaan sebesar $-0,337$ dengan nilai $t$ hitung sebesar 2,156 lebih besar dari nilai t tabel sebesar 2,030 dan nilai signifikansi sebesar 0,038 lebih kecil dari 0,05 hal ini berarti bahwa variabel Umur Perusahaan 


\section{JURNAL NOMINAL / VOLUME IV NOMOR 2 / TAHUN 2015}

mempunyai pengaruh yang signifikan terhadap Audit Delay. Penelitian ini sejalan dengan penelitian yang dilakukan oleh Novelia Sagita Indra dan Dicky Arisudhana (2012) yang menyatakan bahwa Umur Perusahaan berpengaruh negatif terhadap Audit Delay yang artinya bahwa semakin lama Umur Perusahaan maka Audit Delay akan semakin singkat. Semakin lama umur perusahaan, investor akan menilai bahwa perusahaan tersebut akan semakin efisien sehingga informasi yang relevan dapat disajikan tepat waktu. Oleh karena itu, semakin lama umur perusahaan maka Audit Delay yang terjadi akan semakin singkat. Hal tersebut dikarenakan perusahaan yang memiliki umur lebih lama dinilai lebih mampu dan terampil dalam mengumpulkan, memproses, dan menghasilkan informasi pada saat diperlukan karena telah memiliki pengalaman yang cukup banyak (Novelia Sagita Indra dan Dicky Arisudhana, 2012).

\section{Pengaruh Profitabilitas Perusahaan} terhadap Audit Delay

Nilai koefisien regresi variabel Profitabilitas Perusahaan sebesar 13,511 dengan nilai t hitung sebesar 2,941 lebih besar dari nilai t tabel sebesar 2,030 dan nilai signifikansi sebesar 0,006 lebih kecil dari 0,05 hal ini berarti bahwa Profitabilitas Perusahaan mempunyai pengaruh yang signifikan terhadap Audit
Delay. Penelitian sejalan dengan penelitian yang dilakukan oleh Novice Lianto dan Budi Hartono (2010) dan Dewi Lestari (2010) yang menyatakan bahwa Profitabilitas Perusahaan berpengaruh terhadap Audit Delay. Perusahaan dengan profitabilitas yang tinggi waktu Audit Delay nya cenderung singkat karena profitabilitas yang tinggi merupakan kabar baik sehingga perusahaan tidak akan menunda untuk mempublikasikan laporan keuangan perusahaan tersebut.

\section{Pengaruh Solvabilitas Perusahaan terhadap Audit Delay}

Nilai koefisien regresi variabel Solvabilitas Perusahaan sebesar -1,651 dengan nilai $\mathrm{t}$ hitung sebesar 0,100 lebih kecil dari nilai $t$ tabel sebesar 2,030 dan nilai signifikansi sebesar 0,921 lebih besar dari 0,05 hal ini berarti bahwa Solvabilitas Perusahaan tidak mempunyai pengaruh yang signifikan terhadap Audit Delay. Penelitian ini sejalan dengan penelitian yang dilakukan oleh Ani Yuliyanti (2011), Solvabilitas Perusahaan tidak mempunyai pengaruh yang signifikan terhadap Audit Delay. Kemampuan perusahaan dalam membayarkan semua utang-utangnya ternyata tidak berpengaruh terhadap Audit Delay. Hal tersebut disebabkan karena standar pekerjaan auditor yang telah diatur dalam SPAP menyatakan bahwa pelaksanaan prosedur audit perusahaan 


\section{JURNAL NOMINAL / VOLUME IV NOMOR 2 / TAHUN 2015}

baik yang memiliki total utang besar dengan jumlah debtholder yang banyak atau perusahaan dengan utang yang kecil dan jumlah debtholder sedikit tidak akan mempengaruhi proses penyelesaian audit laporan keuangan, karena auditor yang ditunjuk pasti telah menyediakan waktu sesuai dengan kebutuhan untuk menyelesaikan proses pangauditan utang (Yugo Trianto dalam Ani Yuliyanti, 2011).

\section{Pengaruh Ukuran KAP terhadap Audit}

\section{Delay}

Nilai koefisien regresi variabel Ukuran KAP sebesar -11,617 dengan nilai t hitung sebesar 1,188 lebih kecil dari nilai t tabel sebesar 2,030 dan nilai signifikansi sebesar 0,243 lebih besar dari 0,05 hal ini berarti bahwa Ukuran KAP tidak mempunyai pengaruh yang signifikan terhadap Audit Delay. Berdasarkan hasil penelitian ini didapatkan bahwa Ukuran KAP tidak berpengaruh terhadap Audit Delay, yang artinya perusahaan LQ 45 yang diaudit oleh KAP non big four juga memiliki Audit Delay yang hampir sama dengan perusahaan LQ 45 yang diaudit oleh KAP big four. Sehingga dapat dikatakan bahwa KAP non big four juga mempunyai tenaga spesialis yang profesional yang mampu melakukan audit secara efisien sehingga mampu menyelesaikan laporan audit dengan tepat waktu sesuai peraturan yang berlaku
(Armanto Witjaksono dan Mega Silvia, 2014). Penelitian ini sejalan dengan penelitian yang dilakukan oleh Armanto Witjaksono dan Mega Silvia (2014), Esynasali Violeta Sebayang (2014) dan Febrianty (2011) yang menyatakan bahwa Ukuran KAP tidak mempunyai pengaruh yang signifikan terhadap Audit Delay.

\section{Pengaruh Opini Auditor terhadap Audit Delay}

Nilai koefisien regresi variabel Opini Auditor sebesar 8,564 dengan nilai t hitung sebesar 1,609 lebih kecil dari nilai t tabel sebesar 2,030 dan nilai signifikansi sebesar 0,038 lebih kecil dari 0,05 hal ini berarti bahwa Opini Auditor tidak mempunyai pengaruh yang signifikan terhadap Audit Delay. Penelitian ini sejalan dengan penelitian yang dilakukan oleh Ani Yuliyanti (2011) yang menyatakan bahwa Opini Auditor tidak mempunyai pengaruh yang signifikan terhadap Audit Delay. Dari hasil peneitian Ani Yuliyanti (2011) dapat disimpulkan bahwa lamanya proses audit belum menjamin akan dikeluarkannya pendapat wajar tanpa pengecualian (unqualified opinion). 
Pengaruh Ukuran Perusahaan, Umur Perusahaan, Profitabilitas Perusahaan, Solvabilitas Perusahaan, Ukuran KAP, dan Opini Auditor terhadap Audit Delay

Hasil pengujian menunjukkan bahwa Ukuran Perusahaan, Umur Perusahaan, Profitabilitas Perusahaan, Solvabilitas Perusahaan, Ukuran KAP, dan Opini Auditor berpengaruh terhadap Audit Delay. Setelah dilakukan perhitungan dengan analisis regresi ganda dengan menggunakan program SPSS diperoleh nilai koefisien regresi $\mathrm{X}_{1}$ sebesar 3,875, nilai koefisien regresi $\mathrm{X}_{2}$ sebesar $-0,337$, nilai koefisien regresi $\mathrm{X}_{3}$ sebesar 13,511, nilai koefisien regresi $\mathrm{X}_{4}$ sebesar -1,651, nilai koefisien regresi $\mathrm{X}_{5}$ sebesar $-11,617$, nilai koefisien regresi $\mathrm{X}_{6}$ sebesar 8,564, dan nilai konstanta sebesar -40,311. Persamaan garis regresi berganda sebagai berikut $Y=-40,311+3,875 X_{1}-0,337 X_{2}$ $+13,511 X_{3}-1,651 X_{4}-11,617 X_{5}+$ $8,564 \mathrm{X}_{6}$. Hasil uji F menunjukkan bahwa nilai $\mathrm{F}$ hitung lebih besar dari $\mathrm{F}$ tabel $(3,506>2,37)$, dengan nilai signifikansi lebih kecil dari taraf signifikansi 5\% $(0,008<0,05)$, sehingga dapat disimpulkan bahwa Ukuran Perusahaan, Umur Perusahaan, Profitabilitas Perusahaan, Solvabilitas Perusahaan, Ukuran KAP, dan Opini Auditor memiliki pengaruh secara bersama-sama (simultan) terhadap Audit Delay pada perusahaan LQ 45 yang terdaftar di Bursa Efek Indonesia tahun 2011-2013.

\section{SIMPULAN DAN SARAN}

\section{Simpulan}

a. Ukuran Perusahaan tidak mempunyai pengaruh yang signifikan terhadap Audit Delay pada perusahaan LQ 45 yang terdaftar di Bursa Efek Indonesia tahun 2011-2013. Hal tersebut dibuktikan dengan nilai signifikansi lebih besar dari taraf signifikansi $5 \%$ $(0,228>0,05)$ dan nilai t hitung lebih besar dari nilai $t$ tabel $(1,228<2,030)$.

b. Umur Perusahaan berpengaruh signifikan terhadap Audit Delay pada perusahaan LQ 45 yang terdaftar di Bursa Efek Indonesia tahun 20112013. Hal tersebut dibuktikan dengan nilai signifikansi lebih kecil dari taraf signifikansi $5 \% \quad(0,038<0,05)$ dan nilai $\mathrm{t}$ hitung lebih besar dari nilai $\mathrm{t}$ tabel $(2,156>2,030)$.

c. Profitabilitas Perusahaan berpengaruh signifikan terhadap Audit Delay pada perusahaan LQ 45 yang terdaftar di Bursa Efek Indonesia tahun 20112013. Hal tersebut dibuktikan dengan nilai signifikansi lebih kecil dari taraf signifikansi $5 \% \quad(0,006<0,05)$ dan nilai $\mathrm{t}$ hitung lebih besar dari nilai $\mathrm{t}$ tabel $(2,941>2,030)$. 


\section{JURNAL NOMINAL / VOLUME IV NOMOR 2 / TAHUN 2015}

d. Solvabilitas Perusahaan tidak mempunyai pengaruh signifikan terhadap Audit Delay pada perusahaan LQ 45 yang terdaftar di Bursa Efek Indonesia tahun 2011-2013. Hal tersebut dibuktikan dengan nilai signifikansi lebih besar dari taraf signifikansi $5 \% \quad(0,921>0,05) \quad$ dan nilai $\mathrm{t}$ hitung lebih kecil dari nilai $\mathrm{t}$ tabel $(0,100<2,030)$.

e. Ukuran KAP tidak mempunyai pengaruh yang signifikan terhadap Audit Delay pada perusahaan LQ 45 yang terdaftar di Bursa Efek Indonesia tahun 2011-2013. Hal tersebut dibuktikan dengan nilai signifikansi lebih besar dari taraf signifikansi 5\% $(0,243>0,05)$ dan nilai t hitung lebih kecil dari nilai t tabel $(1,188<2,030)$.

f. Opini Auditor tidak mempunyai pengaruh yang signifikan terhadap Audit Delay pada perusahaan LQ 45 yang terdaftar di Bursa Efek Indonesia tahun 2011-2013. Hal tersebut dibuktikan dengan nilai signifikansi lebih besar dari taraf signifikansi 5\% $(0,117>0,05)$ dan nilai t hitung lebih kecil dari nilai t tabel $(1,609<2,030)$.

g. Ukuran Perusahaan, Umur Perusahaan, Profitabilitas Perusahaan, Solvabilitas Perusahaan, Ukuran KAP, dan Opini Auditor secara simultan berpengaruh signifikan terhadap Audit Delay pada perusahaan LQ 45 yang terdaftar di Bursa Efek Indonesia tahun 2011-2013. Hal tersebut dibuktikan dengan nilai signifikansi tersebut lebih kecil dari taraf signifikansi $5 \%(0,008<0,05)$ dan nilai $\mathrm{F}$ hitung lebih besar dari $\mathrm{F}$ tabel $(3,506>2,37)$.

\section{Saran}

a. Bagi Auditor

Hasil penelitian ini memberikan informasi mengenai rata-rata Audit Delay pada perusahaan LQ 45 dan faktor-faktor yang mempengaruhinya sehingga para auditor dapat mengendalikan faktor-faktor dominan yang mempengaruhi Audit Delay. Dari hasil penelitian ini faktor-faktor yang paling dominan adalah Umur Perusahaan dan Profitabilitas Perusahaan. Auditor disarankan untuk merencanakan pekerjaan lapangan dengan baik agar proses audit dapat dilakukan dengan efektif dan efisien sehingga dapat meminimalkan Audit Delay.

b. Bagi Perusahaan

Perusahaan sebaiknya mengevaluasi kinerja perusahaan secara berkala agar dapat mengendalikan faktor-faktor dominan yang dapat mempengaruhi Audit Delay. Dari hasil penelitian ini faktor-faktor yang paling dominan dalam mempengaruhi Audit Delay 


\section{JURNAL NOMINAL / VOLUME IV NOMOR 2 / TAHUN 2015}

adalah Umur Perusahaan dan

Profitabilitas Perusahaan. Seain itu, perusahaan diharapkan dapat memberikan data-data yang diperlukan selama proses pemeriksaan laporan keuangan sehingga laporan keuangan dapat dipublikasikan lebih awal.

c. Bagi Penelitian Selanjutnya

Penelitian selanjutnya sebaiknya menggunakan sampel jenis perusahaan yang lainnya, menambah variabel independen lain, serta menambah periode penelitian.

\section{DAFTAR PUSTAKA}

Abdul Halim. (2003). Auditing I Dasardasar Auditing Laporan Keuangan Jilid I. Yogyakarta: UPP AMP YKPN.

Ani Yulianti. (2011). Faktor-faktor Yang Berpengaruh Terhadap Audit Delay (Studi Empiris Pada Perusahaan yang Terdaftar di Bursa Efek Indonesia Tahun 2007-2008). Skripsi. Universitas Negeri Yogyakarta.

Andi Kartika. (2009). Faktor-faktor yang Mempengaruhi Audit Delay di Indonesia (Studi Empiris pada Perusahaan-Perusahaan LQ 45 yang Terdaftar di Bursa Efek Jakarta. Jurnal Bisnis dan Ekonomi (Vol. 16 No. 1 Maret 2009 Hal.1-17). Universitas Stikubank Semarang.
Arens, Alvin A., Randal J. Elder, dan Mark S. Beasley. (2006). Auditing dan Jasa Assurance : Pendekatan Terintegrasi. Jakarta: Erlangga.

Armanto Witjaksono dan Mega Silvia. (2014). Analisis Faktor-faktor yang Berpengaruh Terhadap Audit Delay Pada Perusahaan Consumer Goods yang Terdaftar di Bursa Efek Indonesia Periode 2010-2013. Jurnal Akuntansi. Universitas Bina Nusantara.

Camelia Putri Purnamasari. (2012). Analisis Faktor-Faktor yang Mempengaruhi Audit Delay pada Perusahaan LQ 45 yang Terdaftar di Bursa Efek Indonesia. Jurnal Akuntansi. Universitas Gunadarma.

Danang Sunyoto. (2013). Metodologi Penelitian Akuntansi. Bandung : PT. Refika Aditama.

Devi Frildawati. (2009). Analisis FaktorFaktor yang Mempengaruhi Audit Delay (Studi Kasus pada Perusahaan di Bursa Efek Indonesia). Skripsi. Universitas Islam Negeri Syarif Hidayatullah Jakarta.

Dewi Lestari. (2010). Analisis Faktorfaktor yang Mempengaruhi Audit Delay : Studi Empiris pada Perusahaan Consumer Goods yang Terdaftar di Bursa Efek Indonesia. Skripsi. Universitas Diponegoro.

Esynasali Violetta Sebayang. (2014). Analisis Faktor-Faktor yang Mempengaruhi Audit Delay (Studi Empiris pada PerusahaanPerusahaan Perbankan yang Terdaftar di Bursa Efek Indonesia tahun 2010-2012). Skripsi. Universitas Diponegoro.

Febrianty. (2011). Faktor-faktor yang Berpengaruh Terhadap Audit Delay 
Perusahaan Sektor Perdagangan yang Terdaftar di BEI periode 20072009. Jurnal Ekonomi dan Informasi Akuntansi (Vol. 1 No. 3 September 2011). Politeknik PalComTech.

Fitria Kusumawardani. (2012). FaktorFaktor yang Mempengaruhi Audit Delay pada Perusahaan Manufaktur. Accounting Analysis Journal. Universitas Negeri Semaranag.

Haryono Yusuf. (2001). Auditing (Pengauditan) Buku I. Yogyakarta: Sekolah Tinggi Ilmu Ekonomi YKPN.

Imam Ghozali. (2011). Aplikasi Analisis Multivariate Dengan Program IBM SPSS 19. Semarang: Badan Penerbit Universitas Diponegoro.

Kasmir. (2011). Analisis Laporan Keuangan. Jakarta: Rajagrafindo Persada.

Malinda Dwi Apriliane. (2015). Analisis Faktor-Faktor yang Mempengaruhi Audit Delay (Studi Empiris pada Perusahaan Pertambangan yang Terdaftar di Bursa Efek Indonesia Tahun 2008-2013). Skripsi. Universitas Negeri Yogyakarta.

Messier, William F., Steven M. Glover, Douglas F.Prawitt. (2005). Jasa Audit \& Assurance: Pendekatan Sistematis, Edisi 4, Buku 1. Jakarta: Salemba Empat.

Meylisa Januar Iskandar dan Estralita Trisnawati. (2010). Faktor-Faktpr yang Mempengaruhi Audit Report Lag pada Perusahaan yang Terdaftar di Bursa Efek Indonesia. Jurnal Bisnis dan Akuntansi (Vol. 12 No.3 Desember 2010 Hal.175-186). Universitas Tarumanegara.
Mulyadi. (2013). Auditing Buku I. Jakarta : Salemba Empat.

Novelia Sagita Indra dan Dicky Arisudhana. (2012). Faktor-faktor yang Mempengaruhi Audit Delay pada Perusahaan Go Public di Indonesia (Studi Empiris pada Perusahaan Property di Bursa Efek Indonesia tahun 2007-2010). Jurnal Fakultas Ekonomi Budi Luhur (Vol. 1 No.2 Oktober 2012). Universitas Budi Luhur.

Novice Lianto dan Budi Hartono Kusuma. (2010). Faktor-Faktor yang Berpengaruh terhadap Audit Report Lag. Jurnal Bisnis dan Akuntansi (Vol. 12 No.2, Agustus 2010, Halaman 97-106). Universitas Tarumanegara.

Nur Indriantoro dan Bambang Supeno. (2009). Metode Penelitian Bisnis untuk Akuntansi dan Manajemen. Yogyakarta : BPFE Yogyakarta.

Subramanyam dan John J. Wild. (2013). Analisis Laporan Keuangan Buku 2. Jakarta: Salemba Empat.

Sugiyono. (2001). Metode Penelitian Bisnis. Bandung : Alfabeta.

Wiwik Utami. (2006). Analisis Determinan Audit Delay Kajian Empiris di Bursa Efek Jakarta. Bulletin Penelitian. No.9 Ka. Pusat Penelitian dan Dosen FE. Universitas Mercu Buana.

Zaki Baridwan. (2004). Intermediate Accounting. Yogyakarta : BPFE Yogyakarta.

Keuangan. (http://jarcomsys .wordpress.com/2009/10/28/analisisrasio-keuangan/ diakses Minggu, 2 November 2014 pukul 11.15). 
. (2013). Pengujian Hipotesis

(Uji Koefisien Determinasi,Uji F,

Uji t).

(http://girimahendra.blogspot.com/2

013/05/pengujian-hipotesis-uji-

koefisien.html? $\mathrm{m}=1$ diakses

Minggu, 9 November pukul 14.41).

Perusahaan Go Public di

Bursa Efek Indonesia.

(www.sahamok.com/perusahaan-

perusahaan -publik-terbuka-tbk-

emiten-bei-bursa-efek-indonesia/

diakses Rabu, 7 januari 2015 pukul

16.30).

Riza Fathoni. (2011). BEI peringatkan

Lima Emiten. (http://www.bisnis keuangan.kompas.com/read/2011/08 /01/18433445/BEI.

Peringatkan.Lima.Emiten. diakses Minggu, 22 Maret 2015 pukul 09.50).

www.idx.co.id diakses Sabtu 6 Desember 2014 